\title{
Identification and Mapping of Nucleotide Binding Site-Leucine-rich Repeat Resistance Gene Analogs in Bermudagrass
}

\author{
Karen R. Harris ${ }^{1}$ \\ U.S. Department of Agriculture-Agriculture Research Service, Crop Genetics and Breeding Research, \\ 115 Coastal Way, Tifton, GA 31794 \\ Brian M. Schwartz \\ Department of Crop and Soil Sciences, University of Georgia, Tifton Campus, P.O. Box 748, Tifton, \\ GA 31793
}

\author{
Andrew H. Paterson \\ Plant Genome Mapping Laboratory, University of Georgia, Athens, GA 30602
}

Jeff A. Brady

Texas AgriLife Research, 1229 North U.S. Highway 281, Stephenville, TX 76401

AdDitional INDEx words. Cynodon, disease, degenerate oligonucleotides, non-TIR NBS-LRR sequences

\begin{abstract}
Thirty-one partial bermudagrass (Cynodon spp.) disease-resistance gene analogs (BRGA) were cloned and sequenced from diploid, triploid, tetraploid, and hexaploid bermudagrass using degenerate primers to target the nucleotide binding site (NBS) of the NBS-leucine-rich repeat (LRR) resistance gene family. Alignment of deduced amino acid sequences revealed that the conserved motifs of the NBS are present and all sequences have nonDrosophila melanogaster Toll and mammalian interleukin-1 receptor (TIR) motifs. Using a neighbor-joining algorithm, a dendrogram was created and nine groups of deduced amino acid sequences from bermudagrass could be identified from those sequences that span the NBS. Four BRGA markers and 15 bermudagrass expressed sequence tags (ESTs) with similarity to resistance genes or resistance gene analogs were placed on a bermudagrass genetic map. Multiple BRGA and EST markers mapped on T89 linkage groups 1a and 5a and clusters were seen on T89 19 and two linkage groups previously unidentified. In addition, three primers made from BRGA groups and ESTs with similarity to NBS-LRR resistance genes amplify NBS-LRR analogs in zoysiagrass (Zoysia japonica or Z. matrella) or seashore paspalum (Paspalum vaginatum). This gives evidence of conservation of NBS-LRR analogs among the subfamilies Chloridoideae and Panicoideae. Once disease resistance genes are identified, these BRGA and EST markers may be useful in marker-assisted selection for the improvement of disease resistance in bermudagrass.
\end{abstract}

Bermudagrass is a $\mathrm{C} 4$ perennial grass used widely for lawns, sports fields, parks, golf courses, and pastures, and to prevent soil erosion in most of the warmer environments across the world. Common bermudagrass (Cynodon dactylon, $2 n=4 \mathrm{x}=$ 36) can be a serious weed that is difficult to eradicate because of stolons that readily root at the nodes, deep rhizomes, and seed production (Webster et al., 2004). Another type of bermudagrass, african bermudagrass (Cynodon transvaalensis, $2 n=$ $2 \mathrm{x}=18$ ), is a very fine-textured grass that has poor wear and pest tolerance compared with the improved triploid hybrids (Hanna, 1986; Wiecko, 2007). Improvement of bermudagrass has occurred by selection for turfgrass adaptability and aesthetic traits from common bermudagrass such as 'Tiflawn' (Hein, 1953) and the release of sterile triploid hybrids $(2 n=$ $3 \mathrm{x}=27$ ) between $C$. transvaalensis and $C$. dactylon such as 'Tifgreen' and 'Tifdwarf' (Burton, 1966; Hein, 1961). Most

Received for publication 30 Nov. 2009. Accepted for publication 22 Jan. 2010. We thank Mrs. Jacolyn Merriman for technical assistance, Drs. Wayne Hanna and Earl Elsner for plant material, and Amnon Levi for use of some degenerate primers.

The mention of trade names or commercial products in this publication is solely for the purpose of providing specific information and does not imply the recommendation or endorsement by the U.S. Department of Agriculture.

${ }^{1}$ Corresponding author. E-mail: Karen.Harris@ars.usda.gov. new releases are vegetatively propagated triploid hybrids that are more pest resistant, make a denser turf, tolerate close mowing, have fewer seedheads, and are more uniform than common bermudagrass (Webster et al., 2003).

Bermudagrass is susceptible to a wide range of fungi (Pratt, 2003), nematodes (Giblin-Davis et al., 1992), and insects (Chang et al., 1985; Reinert and Busey, 2001; Shortman et al., 2002), although few are considered to be serious issues when properly managed. The major fungal diseases of bermudagrass include spring dead spot caused by Ophiosphaerella herpotricha, $O$. korrae, and $O$. narmari, brown patch caused by Rhizoctonia spp., and dollar spot caused by Sclerotinia homoeocarpa (Baird et al., 1998; Taliaferro, 2003). Serious insect pests include southern and tawny mole crickets (Scaptericus acletus and S. vicinus), tropical sod webworm (Herpetogramma phaeopteralis), and fall armyworm (Spodoptera frugiperda) (Taliaferro, 2003). Nematodes, including sting (Belonolaimus spp.), lance (Hoplolaimus spp.), root-knot (Meloidogyne spp.), and spiral (Helicotylenchus spp.), also may cause serious injury to bermudagrass (Crow, 2002; White and Dickens, 1984).

Widespread monoculture of only a few cultivars such as Tifdwarf and Tifway could cause new resistant strains of diseases and pests to develop by selection pressure (Taliaferro, 1995). To date, the development of cultivars with resistance to 
diseases or pests of interest in many plant species has been accomplished by use of traditional plant breeding, the use of marker-assisted selection (MAS) to transfer resistance genes from a resistant genotype to a cultivar, and by genetic transformation. In cases such as diseases that are difficult to phenotype or for which the resistance gene is recessive (noting that many bermudagrass clones are intolerant of selfing), MAS may be the preferred method to develop a product with resistance to a desired agent, as traditional plant breeding often takes years of selection and testing (Xu and Couch, 2008). Currently, transformation of resistance genes from an organism to a desired cultivar (genetic modification) is limited by challenges such as time to receive regulatory approval, public concern about genetic modification, and the specialized handling cost associated with these materials (Casler, 2006; McHughen and Smyth, 2008; Redenbaugh and McHughen, 2004; Sawahel, 1994).

Isolation and characterization of 40 plant resistance genes that confer resistance to a wide range of pathogens such as bacteria, viruses, fungi, oomycetes, and nematodes have been identified. The most abundant class of resistance genes (75\%) encodes a centrally located nucleotide binding site (NBS) and a carboxyl terminal block of leucine-rich repeat (LRR) (Radwan et al., 2008). Two major subfamilies of NBS-LRR proteins exist. The Toll and mammalian interleukin-1 receptor (TIR)-NBS-LRR subfamily, found only in dicots, contain an amino-terminalsignaling domain with homology to the TIR (Collier and Moffett, 2009). The coiled-coil (CC)-NBS-LRR subfamily, found in monocots and dicots, contains a CC structure in the aminoterminal signal domain (DeYoung and Innes, 2006).

Studies using degenerate polymerase chain reaction (PCR) primers targeting conserved sequences within and adjacent to the NBS have enabled identification of NBS-LRR gene analogs from many plant species (for a review, see McHale et al., 2006). The conserved sequences of the NBS domain include the phosphate-binding loop (P-loop), kinase-2 motif, kinase-3a motif, as well as conserved blocks of unknown function that include RNBS-A, RNBS-C, Gly-Leu-Pro-Leu (GLPL), RNBS$\mathrm{D}$, and the hydrophobic domain (HD) (De Young and Innes, 2006). Similar to NBS-LRR cloned resistance genes, many NBS-LRR analogs are clustered in the genomes of various plant species (Brotman et al., 2002). Furthermore, several of these NBS-LRR analogs have been found to be linked to diseaseresistance loci (Deng et al., 2000). For example, in potato (Solanum tuberosum), two NBS-LRR resistance gene analogs (RGAs) had very close linkage with the root cyst nematode resistance locus Grol (Leister et al., 1996).

Little is known about BRGA or their location in the bermudagrass genome. Therefore, the objective of this research was to identify RGAs in bermudagrass, to create markers tagging these NBS-LRR analogs, and to identify linkage groups where NBS-LRR analogs map. These goals may prove useful for identifying DNA markers for MAS once disease-resistance genes are identified and mapped. Furthermore, cross-species amplification and cloning of disease-resistance expressed sequence tag (EST) analogs were evaluated in other important turfgrass species to determine if the sequences are conserved among the subfamilies of Poaceae.

\section{Material and Methods}

Plant material uSed for isolation of BRGA. Clonally propagated plant material of T89 and PI 291586 (C. dactylon,
$2 n=4 \mathrm{x}=36)$, T574 $(C$. transvaalensis, $2 n=2 \mathrm{x}=18)$, 'TifGrand', 'Tifway' $(C$. dactylon $\times C$. transvaalensis $2 n=$ $3 \mathrm{x}=27)$, and 'Tifton 10 ' ( $C$. dactylon, $2 n=6 \mathrm{x}=54)$ bermudagrass genotypes was obtained from the turfgrass breeding program at the University of Georgia, Tifton, except for PI 291586, which was obtained from the U.S. Department of Agriculture Southern Regional Plant Introduction (PI) Station in Griffin, GA. PI 291586 has resistance to tawny mole cricket (Reinert and Busey, 2001). 'TifGrand' has better tawny mole cricket resistance than 'Tifway' and 'TifSport', but is less resistant to the bermudagrass mite (Aceria cynodoniensis) than the latter (Hanna et al., 2010). 'Tifway' has very high tolerance to the two-lined spittlebug (Hemiptera:Cercopidae) (Shortman et al., 2002) and has tolerance to sting nematodes (Giblin-Davis et al., 1992). 'Tifton10' is a highly preferred host to fall armyworm larvae (Chang et al., 1985), but is not preferred by fire ant (Solenopsis invicta) (Reinert, 2009).

BERMUdAgRASS MAPPING POPULATION. $\mathrm{F}_{1}$ progeny of a cross between T574 (C. transvaalensis, 2x) and T89 (C. dactylon, 4x) were used to create a bermudagrass linkage map based on single-dose restriction fragments (Bethel et al., 2006). The mapping population was created by W. Hanna (University of Georgia, Tifton). DNA was extracted from $121 \mathrm{~F}_{1}$ field-grown individuals using a PureLink DNA Purification Kit (Invitrogen, Carlsbad, CA).

DNA EXTRACTion AND BRGA isolation. Fresh tissue from the six genotypes was collected, cut into $\approx 5-\mathrm{mm}$ pieces, inserted into 2-mL microtubes with stainless steel beads, and placed in liquid nitrogen. Tissue was then ground using a vortexer, and tubes containing the tissue were replaced in liquid nitrogen to prevent thawing. DNA was isolated using a DNeasy Plant Mini Kit (Qiagen, Valencia, CA). DNA was run on a $1 \%$ agarose gel and analyzed on a Nanodrop 2000c (Thermo Scientific, Wilmington, DE) to control for quality and quantity. BRGA were amplified using the previously published degenerate primers to amplify NBS-LRR RGAs (Table 1). Amplicons were generated in a $25-\mu \mathrm{L}$ reaction volume. Each reaction contained $5 \mu \mathrm{L}$ of Green GoTaq ${ }^{\circledR}$ reaction buffer (Promega, Madison, WI), $2.5 \mu \mathrm{L}$ of $25 \mathrm{mM} \mathrm{MgCl}_{2}, 2.5 \mu \mathrm{L}$ of 2.5 mM dNTP mix, $0.25 \mu \mathrm{L}$ of $100 \mu \mathrm{M}$ degenerate primer pair, 0.25 $\mu \mathrm{L}$ of GoTaq ${ }^{\circledR}$ DNA polymerase (Promega), $12.25 \mu \mathrm{L}$ of water, and $2 \mu \mathrm{L}$ of DNA at $10 \mathrm{ng} \cdot \mu \mathrm{L}^{-1}$. Thermocycling conditions began with $94{ }^{\circ} \mathrm{C}$ for $3 \mathrm{~min}$, followed by 36 cycles of $94^{\circ} \mathrm{C}$ for $30 \mathrm{~s}, 45^{\circ} \mathrm{C}$ for $1 \mathrm{~min}$, and $72^{\circ} \mathrm{C}$ for $1 \mathrm{~min}$ and $10 \mathrm{~s}$. A final extension was performed at $72{ }^{\circ} \mathrm{C}$ for $10 \mathrm{~min}$. PCR products were run on a $1 \%$ agarose gel and bands of the expected size were excised and purified with a Cyclo-Pure agarose gel extraction kit (Amresco, Solon, OH). Fragments were ligated into a pGEM T-Easy vector (Promega) and transformed into Turbo cells (Genlantis, San Diego). Blue-white screening was performed and clones were grown overnight in Luria broth with ampicillin $\left(100 \mu \mathrm{g} \cdot \mathrm{mL}^{-1}\right)$ and plasmids were purified using a Pure Yield Miniprep System (Promega). Purified plasmids were digested with EcoRI (New England Biolabs, Ipswich, MA) to select for those plasmids with inserts of the expected size. Inserts were sequenced using the Big Dye Terminator, version 3.1, cycle sequencing kit (Applied Biosystems, Carlsbad, CA) and were run on an ABI 3100 Genetic Analysis System at the Laboratory for Plant Genome Technologies (Texas A\&M University, College Station).

BRGA SEQUENCE ANALysis. Nucleotide sequences were analyzed using Sequencer, version 4.9 (GeneCodes, Ann 
Table 1. Degenerate primers corresponding to conserved domains of resistance genes that were used to amplify bermudagrass-resistance gene analogs.

\begin{tabular}{lllr}
\hline Protein region $^{z}$ & \multicolumn{1}{c}{ Primer } & \multicolumn{1}{c}{ Primer sequence $\left(5^{\prime} 3^{\prime}\right)$} & Reference \\
\hline P-loop & NBS-F1/LM638 & GGI GGI GTI GGI AAI ACI AC & Badwan et al., 2008 \\
& 16409 & GGI GGI WSI GGI AAR ACI AC & Brotman et al., 2002 \\
PLP & GGI GGI RTI GGI AAR ACI AC & Brotman et al., 2002 \\
HD & antiHD1 & ARN GGI ARI CCY TTR CA & Deng et al., 2000 \\
& R11 & AGI GC(A/C/T) AGN GGN AGN CC & Radwan et al., 2008 \\
& NBS-R1 & IAG IGC IAG IGG IAG ICC & Kanazin et al., 1996 \\
\hline
\end{tabular}

"P-loop = phosphate-binding loop, $\mathrm{HD}=$ hydrophobic domain.

Arbor, MI) and vector sequence was removed using VecScreen (National Center for Biotechnology Information, 2009). Sequence similarity queries were submitted to GenBank using the BLASTn and BLASTx algorithm from the National Center for Biotechnology Information. Those sequences with similarity to resistance genes or RGA were translated using ExPASy (Gasteiger et al., 2003). Deduced amino acid sequences were aligned using AliBee (Brodsky et al., 1992) in the CLUSTAL W (1.60) format and the Geneious version 4.7.4 software program (Drummond et al., 2009) (Fig. 1). Using the tree builder module of the Geneious software, the genetic distance was calculated between all amino acid sequences using the Jukes-Cantor model (Jukes and Cantor, 1969) and trees were created using the neighbor-joining algorithm. A bootstrap analysis was performed with 1000 repetitions, and branch support of at least $50 \%$ is shown on the dendrogram. BRGA

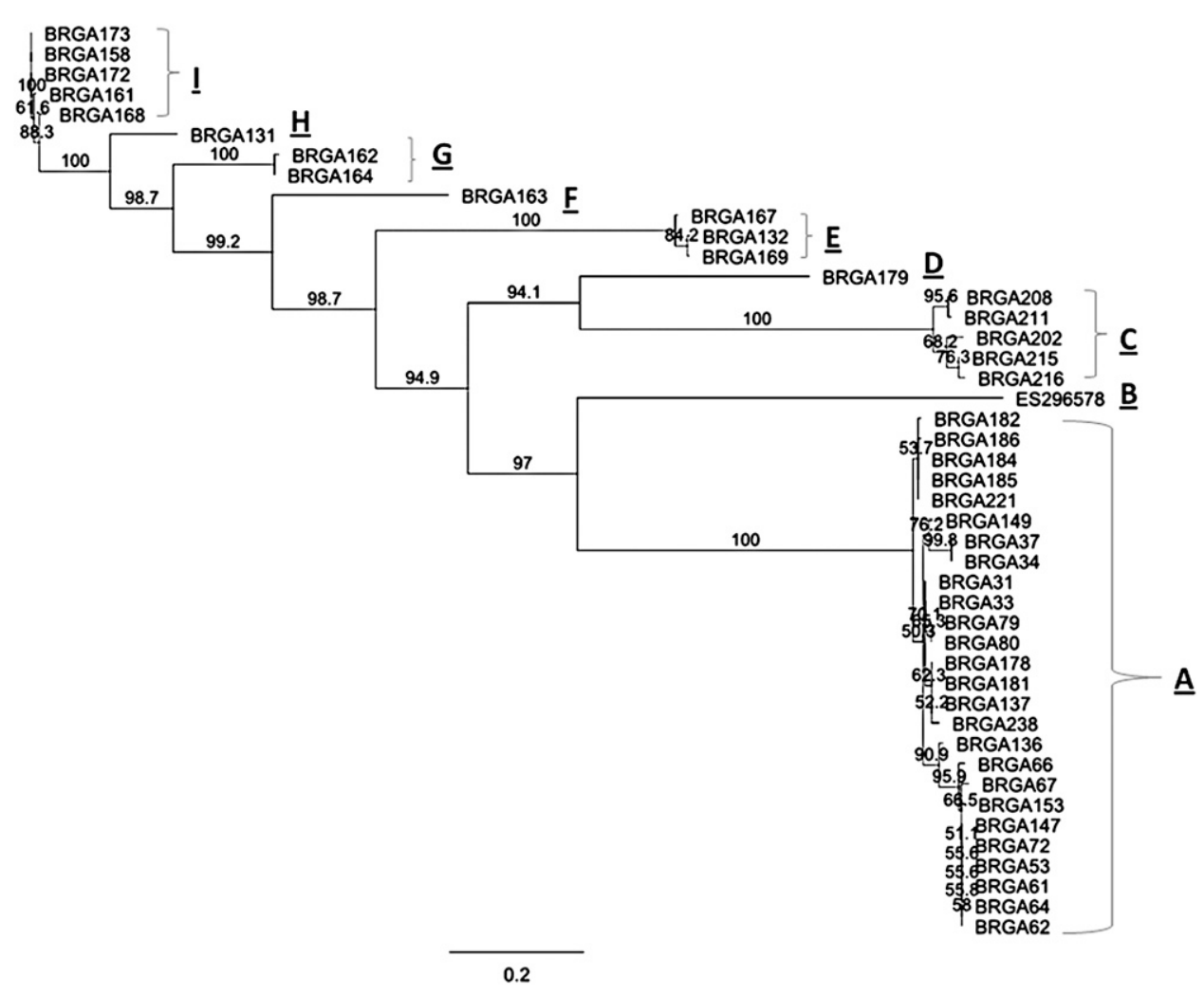

Fig. 1. Neighbor-joining tree with groupings based on an alignment of 44 deduced amino acid sequences of bermudagrass-resistance gene analogs (BRGA) and expressed sequence tag ES296578. Group assignments (AI) and bootstrap values greater than $50 \%$ are shown. Scale bar represents the number of amino acid substitutions per site. were compared with known resistance genes by retrieving the amino acid sequences from GenBank for flax (Linum usitatissimum) L6 (U27081) and $M$ (U73916); rice (Oryza sativa) Pib (AB013449), XA1 (AB002266.1), and Pit (AB379817); Arabidopsis thaliana RPS2(U12860), RPM1 (NM_111584), RPP13 (AF209731-1), RFL1 (AF074916), and RPP8 (AF089710); tomato (Solanum lycopersicum) PRF (U65391), I2C-1 (AAB63274), and RPP8 (AF089710). Ornamental nightshade (Solanum bulbocastanum) genes Rpi-bt1 (ACI16480) and B149 (AAR29073) were also compared with BRGA as they had high BLASTx similarity to BRGA groups. These sequences were trimmed to include only the P-loop to the hydrophobic domain. Trees were created using the neighbor-joining algorithm as described above.

IDENTIFICATION OF DISEASE-RESISTANCE BERMUDAGRASS EST ANALOGS. ESTs with similarity to disease-resistance proteins were mined from an Excel spreadsheet (Microsoft, Redmond, WA) provided in the supplemental material of a bermudagrass EST study that listed the strongest BLASTx hit to each EST (Kim et al., 2008). The keywords "NB-ARC," "NBSLRR," "disease," "disease resistance," and "resistance" were used to identify those ESTs with similarity to disease-resistance proteins (Supplemental Table 1; see the online version of this article at ashs.org to view the table).

GENETIC MAPPING OF BRGA AND DISEASE-RESISTANCE EST ANALOGS. Primers were developed from a member of each BRGA group (Fig. 2, list of groups): those BRGA that contain stop codons, and those ESTs that have similarity to genes involved with disease resistance (polymorphic markers listed in Supplemental Table 2; see the online version of this article at ashs.org to view the table). These BRGA and ESTs were amplified and fluorescently labeled for detection using a modified M13-tailed primer method (Boutin-Ganache et al., 2001). PCR reactions were in a 10 $\mu \mathrm{L}$ volume and contained $2 \mu \mathrm{L}$ of $5 \times$ Clear GoTaq ${ }^{\circledR}$ reaction buffer 


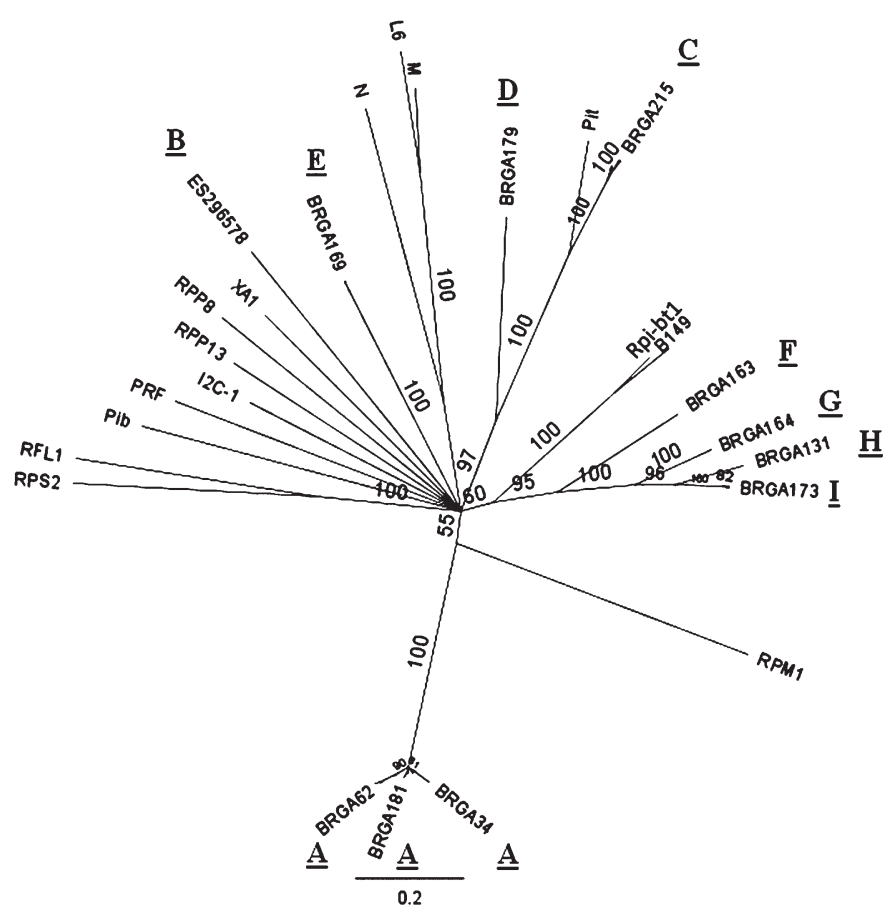

Fig. 2. Neighbor-joining tree of deduced amino acid sequences from 44 bermudagrass-resistance gene analogs (BRGA) with known deduced amino acid sequences of nucleotide binding site-leucine-rich repeat resistance genes. Letters (A-I) by each BRGA or expressed sequence tag represent their Group from Fig. 1. Toll and mammalian interleukin-1 receptor (TIR) motifs are present in the deduced amino acid sequences of $L 6, M$, and $N$. The scale at the bottom of the figure represents amino acid similarity. Bootstrap values greater than $50 \%$ are shown.

(Promega), $1 \mu \mathrm{L}$ of $25 \mathrm{~mm} \mathrm{MgCl}_{2}, 0.8 \mu \mathrm{L}$ of $2.5 \mathrm{~mm}$ dNTP mix, $0.5 \mu \mathrm{L}$ of M13-tagged forward primer at $1 \mu \mathrm{M}, 0.5 \mu \mathrm{L}$ of reverse primer at $1 \mu \mathrm{M}, 1.0 \mu \mathrm{L}$ of $1 \mu \mathrm{M} \mathrm{M} 13$ primer (M13-TGTAAAACGACGGCCAGT) fluorescently labeled with the IRDye ${ }^{\circledR} 800 \mathrm{CW}$ flurophore (Eurofins MWG Operon, Huntsville, AL), $0.04 \mu \mathrm{L}$ of GoTaq ${ }^{\circledR}$ DNA polymerase (Promega), $3.16 \mu \mathrm{L}$ of water, and $1 \mu \mathrm{L}$ of DNA at $2.5 \mathrm{ng} \cdot \mu \mathrm{L}^{-1}$. Thermocycling conditions were as above except that a total of 39 cycles was used and the annealing temperature for each marker is stated in Supplemental Table 2. For some BRGA or ESTs, the polymorphism between T89 and T574 could be resolved on agarose and did not need to be fluorescently labeled. For these PCR products, PCR parameters were the same as for the cross-species amplification listed above, except that the annealing temperature listed in Supplemental Table 2 was used. Two microliters of PCR product was combined with $5 \mu \mathrm{L}$ of Blue Stop (LI-COR $®$ Biosciences, Lincoln, NE), and $0.35 \mu \mathrm{L}$ of this mixture was loaded on a $6.5 \%$ acrylamide gel using a LI-COR® Biosciences 4300 DNA Analyzer. Amplicons that were monomorphic between T89 and T574 were digested with HpaII, EcoRI, EcoRV, and AatII following the manufacturer's protocols (New England Biolabs) to try to generate polymorphism between the parents. Ideal annealing temperatures to enhance the polymorphism between T89 and T574 were found by performing an annealing temperature gradient from 45 to $70{ }^{\circ} \mathrm{C}$. Each individual of the genetic mapping population was loaded in duplicate and bands were scored visually, entered into Excel, and imported into Joinmap ${ }^{8} 4$ (Van Ooijen, 2006). BRGA or EST marker segregation data was combined with the segregation data from the T89 and T574 maps previously created (Bethel et al., 2006) and markers were assigned to groups with a logarithm of the odds of at least five.

Cross-species amplification of BRGA or diseaseRESISTANCE EST ANALOGS. Zoysiagrass (Z. japonica cultivars Empire, JaMur, and Meyer; Z. matrella cultivars Zeon, Emerald, and Diamond), st. augustinegrass (Stenotaphrum secundatum cultivars Sapphire, FX-10, Mercedes, Raleigh, Palmetto, Captiva, Delta Shade, and Classic), seashore paspalum ( $P$. vaginatum cultivars SeaIsle 1, SeaIsle 2000, and UGA31), bentgrass (Agrostis palustris, collected by E. Elsner of the University of Georgia, Athens), and centipedegrass (Eremochloa ophiuroides cultivars TifBlair and Common) samples were obtained to test for BRGA conservation among varying turf species. Amplicons were generated in a $20-\mu \mathrm{L}$ reaction volume. Each reaction contained $4 \mu \mathrm{L}$ of $5 \times$ Green GoTaq ${ }^{\circledR}$ reaction buffer (Promega), $2 \mu \mathrm{L}$ of $25 \mathrm{~mm} \mathrm{MgCl}_{2}, 1.6 \mu \mathrm{L}$ of 2.5 mM dNTP mix, $2 \mu \mathrm{L}$ of $1 \mu \mathrm{M}$ forward and reverse primer pair, $0.08 \mu \mathrm{L}$ of GoTaq ${ }^{\circledR}$ DNA polymerase (Promega), $8.32 \mu \mathrm{L}$ of water, and $2 \mu \mathrm{L}$ of DNA at $2.5 \mathrm{ng} \cdot \mu \mathrm{L}^{-1}$. Thermocycling conditions were the same as listed above for BRGA isolation. PCR amplicons were gel extracted, cloned, and sequenced as previously described above. Sequences were translated and aligned using the same methods as described for the BRGA sequence analysis.

\section{Results}

ISOLATION AND IDENTIFICATION OF BRGA SEQUENCES. NBSLRR analogs in bermudagrass were amplified by the use of degenerate primer pairs NBSF1/ NBSR1, PLP/antiHD1, PLP/ NBSR1, LM637/LM638, and 16409/R11 (Table 1) from six genotypes representing diploid, triploid, tetraploid, and hexaploid bermudagrass. Amplicons of the expected size $(\approx 500 \mathrm{bp})$ were gel extracted and cloned. Sixty-four clones were sequenced, of which 49 clones had similarity to resistance genes. Fifteen clones had sequences with similarity to retrotransposons, secretion proteins, and hypothetical proteins. The 49 BRGA (accession numbers GU246998-GU247046) were translated and the deduced amino acid sequences of five BRGA (BRGA38, BRGA81, BRGA 201, BRGA220, and BRGA229) contained stop codons. These five BRGA, along with 13 sequences that were nearly identical to other BRGA sequences, were excluded from the amino acid alignment (Supplemental Fig. 1; see the online version of this article at ashs.org to view the figure).

Alignment of 31 BRGA deduced amino acid sequences revealed that conserved NBS motifs are present (Supplemental Fig. 1). The P-loop and hydrophobic domain (which served as degenerate primer sites), RNBS-A-non-TIR, kinase-2, and RNBS-B could be identified in all sequences. The consensus sequence for the P-loop was GG(V/R)GKTT, the RNBS-Anon-TIR was $(\mathrm{F} / \mathrm{L})(\mathrm{E} / \mathrm{D} / \mathrm{S} / \mathrm{Q})(\mathrm{C} / \mathrm{L} / \mathrm{R} / \mathrm{I})(\mathrm{A} / \mathrm{K} / \mathrm{R} / \mathrm{I} / \mathrm{P})(\mathrm{A} / \mathrm{L} / \mathrm{M} /$ I)W $(\mathrm{V} / \mathrm{Y} / \mathrm{L} / \mathrm{H})(\mathrm{A} / \mathrm{C})(\mathrm{V} / \mathrm{I})(\mathrm{S} / \mathrm{T})(\mathrm{Q} / \mathrm{K} / \mathrm{E} / \mathrm{D})(\mathrm{T} / \mathrm{N} / \mathrm{Y} / \mathrm{E} / \mathrm{D} / \mathrm{S})(\mathrm{F} /$ $\mathrm{Y})$, the kinase-2 domain was $(\mathrm{L} / \mathrm{F})(\mathrm{V} / \mathrm{L})(\mathrm{V} / \mathrm{I}) \mathrm{LD}(\mathrm{D} / \mathrm{N})(\mathrm{I} /$ $\mathrm{V}) \mathrm{W}$, the RNBS-B domain was $(\mathrm{G} / \mathrm{R} / \mathrm{N})(\mathrm{S} / \mathrm{C} / \mathrm{T} / \mathrm{R})(\mathrm{R} / \mathrm{T} / \mathrm{S} / \mathrm{V} /$ $\mathrm{L})(\mathrm{V} / \mathrm{I} / \mathrm{T})(\mathrm{V} / \mathrm{I} / \mathrm{L} / \mathrm{P})(\mathrm{I} / \mathrm{V} / \mathrm{M}) \mathrm{T}(\mathrm{T} / \mathrm{I} / \mathrm{S})(\mathrm{R} / \mathrm{Q})(\mathrm{S} / \mathrm{L} / \mathrm{K} / \mathrm{D})$, and the hydrophobic domain was GLPLAL. Although one must note that the consensus sequence found in the P-loop and the HD domains is conditioned by the degenerate primers used in the experiment and sequences differing from these sequences may 
not be amplified. The presence of a RNBS-A-non-TIR domain and a tryptophan at the end of the kinase- 2 domain indicates that all sequences have motifs of non-TIR-NBS-LRR resistance genes (Meyers et al., 1999).

Using the neighbor-joining algorithm, a dendrogram was created from all 44 BRGA, from which eight groups were identified (Fig. 1, A and C-I). The largest cluster, Group A, contains 26 BRGA with sequence similarity to a barley (Hordeum vulgare)-resistance protein analog (CAD45036). Group A sequences were identified from all degenerate primer pairs tested (Table 2). Degenerate primer pairs LM637/LM638 and PLP/NBSR1 amplified BRGA clustering in Groups C and $\mathrm{D}$, respectively. The primer pair PLP/antiHD1 amplified BRGA that clustered into five groups (Table 2, Groups E-I). BRGA were amplified from all six genotypes, with the largest number of BRGA groups amplified from 'TifGrand' (Table 2, five groups), followed by 'Tifton 10' and T89 (Table 2, four groups). BRGA were isolated from 'Tifway' and T574, which contained BRGA that clustered in only one group (Table 2, 'Tifway' Group A and T574 Group I). All BRGA had strong BLASTx similarity to NBS-LRR protein analogs from the monocots barley, rice, sugarcane (Saccharum officinarum), and finger millet (Eleusine coracana), except those BRGA clustered in Group C, which have similarity to a characterized rice NBSLRR resistance gene, Pit, that enables race-specific resistance against the fungal pathogen Magnaporthe grisea (Hayashi and Yoshida, 2009). From the amino acid alignment, a distance matrix was created displaying the number of substitutions per site between BRGA. Distance values ranged from 0 (identical sequences) to 1.38 for BRGA202 and BRGA216 when compared with BRGA34. BRGA202 and BRGA216 were assigned to Group $\mathrm{C}$ whereas BRGA34 was assigned to Group A.

The nucleotide sequence of the BRGA spanned from 503 to 538 bp with similarly sized BRGA tending to have similar amino acid sequences. BRGA nucleotide sequences ranges were 536 to 538 bp for Group A, 503 and 509 bp for Group C, 504 bp for Group D, 503 and 504 bp for Group E, 509 bp for Group F, 512 and 514 bp for Group G, 515 bp for Group H, and 518 bp for Group I. After excluding the P-loop and HD, which served as degenerate primer sites, many of the groups of BRGA have different motifs for the RNBS-A-non-TIR, kinase-2, and RNBS-B (Supplemental Fig. 1). For example, each BRGA group contains a different amino acid sequence for the RNBS-B and RNBS-A-non-TIR motifs.
Deduced amino acid sequences spanning the P-loop to the HD from 44 BRGA and 13 known NBS-LRR resistance genes from flax, rice, $A$. thaliana, ornamental nightshade, and tomato were compared using the neighbor-joining algorithm on aligned sequences (Fig. 2, overlapping labels excluded). A representative sequence from each BRGA can be seen for all groups except Group A, which contained three sequences and may suggest that this group could be further subdivided. Genes classified as TIR-NBS-LRRs clustered within one group (Fig. 2, $L 6, M$, and $N)$. Furthermore, the Pit gene from rice, which confers race-specific resistance against $M$. grisea (Hayashi and Yoshida, 2009), was similar to Group C sequences (Fig. 2). This similarity is in agreement with Group C sequence BLASTx data (Table 2). The ornamental nightshade genes B149 and Rpi-bt1, which confer broad spectrum resistance to Phytophthora infestans in transgenic cultivated potato and tomato (Oosumi et al., 2009; van der Vossen et al., 2003), had weak similarity to Group F-I sequences.

IDENTIFICATION OF BERMUDAGRASS DISEASE-RESISTANCE EST ANALOGS. A recent bermudagrass EST study using genotype T89 identified 9414 unigenes (Kim et al., 2008). From these, 24 unigenes were identified with similarity to genes involved in disease resistance (Supplemental Table 1). Five of these 24 unigenes, ES304944, ES303684, ES296578, ES295859, and ES296552, could be translated without stop codons and could be aligned to the BRGA sequences. Only one EST, ES296578, was found to contain the entire P-loop to the HD sequence. ES296578 was compared with the BRGA as well as known R genes (Figs. 1B and 2) and formed its own group.

MAPPING OF BRGA AND ESTS WITH SIMILARITY TO DISEASERESISTANCE GENES OR DISEASE RGA. Six primer pairs (BRGA131, BRGA163, BRGA167, BRGA179, BRGA208, and ES296578) generated from the eight BRGA groups and ES296578, each of which had an open reading frame that spanned the P-loop to the HD, generated six polymorphic markers between T89 and T574 (Supplemental Table 2). Of these six markers, only BRGA179, BRGA208, and ES296578 were found to segregate among the $F_{1}$ progeny (note that only polymorphisms that are heterozygous in diploid $\mathrm{T} 574$, or single/double dose in autotetraploid T89, would be expected to segregate in the $F_{1}$ progeny). Of those markers designed from five BRGA containing stop codons in the NBS (BRGA38, BRGA81, BRGA220, BRGA201, and BRGA229), five markers were polymorphic, and two BRGA segregated at three

Table 2. Degenerate primers used to amplify each bermudagrass-resistance gene analog (BRGA) group, genotypes of sequences generated that were assigned to each BRGA group, and BLASTx similarity of each BRGA group with top hit (GenBank accession number, organism, e-value range) are shown.

\begin{tabular}{|c|c|c|c|c|c|c|}
\hline Group $^{z}$ & Primers & Genotypes & Homology & $\begin{array}{c}\text { GenBank } \\
\text { accession no. }\end{array}$ & Organism & $\begin{array}{l}\text { e-value } \\
\text { (range) }\end{array}$ \\
\hline A (26) & $\mathrm{All}^{\mathrm{y}}$ & All but T574 & NBS-LRR-like protein & CAD45036 & Hordeum vulgare & $2 \mathrm{e}^{-26}$ to $5 \mathrm{e}^{-52}$ \\
\hline $\mathrm{C}(5)$ & LM637/LM638 & $\begin{array}{l}\text { TifGrand,T89, } \\
\text { and Tifton } 10\end{array}$ & NBS-LRR protein $P i t$ & BAH20861 & Oryza sativa & $3 \mathrm{e}^{-53}$ to $5 \mathrm{e}^{-58}$ \\
\hline $\mathrm{D}(1)$ & PLP/NBSR1 & PI 291586 & NBS-LRR-like protein & ABK57113 & Saccharum officinarum & $2 \mathrm{e}^{-69}$ \\
\hline E (3) & PLP/antiHD1 & T89 and Tifton 10 & NB-ARC domain & ABA93733 & O. sativa & $2 \mathrm{e}^{50}$ to $2 \mathrm{e}^{-41}$ \\
\hline $\mathrm{F}(1)$ & PLP/antiHD1 & TifGrand & NBS-LRR-like protein & BAD08985 & O. sativa & $2 \mathrm{e}^{-69}$ \\
\hline $\mathrm{H}(1)$ & PLP/antiHD1 & Tifton 10 & NBS-LRR-like protein & ABW04964 & Eleusine coracana & $2 \mathrm{e}^{-56}$ \\
\hline $\mathrm{I}(5)$ & PLP/antiHD1 & T574, TifGrand, and T89 & NBS-LRR-like protein & ABW04965 & E. coracana & $3 \mathrm{e}^{-62}$ to $4 \mathrm{e}^{-62}$ \\
\hline
\end{tabular}

${ }^{\mathrm{z} N u m b e r s ~ s h o w n ~ i n ~ p a r e n t h e s e s ~ r e p r e s e n t ~ t h e ~ n u m b e r ~ o f ~ B R G A ~ a s s i g n e d ~ t o ~ e a c h ~ g r o u p . ~}$

${ }^{y}$ NBSF1/NBSR1, PLP/antiHD1, PLP/NBSR1, LM637/LM638, and 16409/R11. 
loci (BRGA201 and BRGA229a and b) in the $F_{1}$ progeny (Supplementary Table 2). Primers were developed for the remaining ESTs that had similarity to disease-resistance genes or disease-resistance analogs (Supplemental Tables 2 and 3; see the online version of this article at ashs.org to view the tables). Excluding ES296578, 20 primer pairs designed for each ESTs were polymorphic between the mapping parents, forming 23 markers (three EST markers, ES292682, ES299682, and ES304457, had two alleles), and yet only 15 EST markers were segregating in the $F_{1}$ progeny. Of the 21 total polymorphic markers segregating in the $F_{1}$ progeny, 13 could be placed on reported bermudagrass linkage groups (Table 3 ), noting that the present map is estimated to be only about $61 \%$ complete (Bethel et al., 2006): Two EST markers mapped on each of T89 linkage groups 1a and 5a; one EST marker each on T574 1a, T89 3c, T89 4c, T89 6a; one BRGA marker on T89 12, one EST marker on T89 13, and three EST or BRGA markers on T89 linkage group 19. Markers that grouped together, but not on the previously identified linkage groups, include ES296578 with ES299276 (4.4 cM) and ES303684 with ES303694 (15 $\mathrm{cM})$.

Conservation of BRGA among turf SPECies. Primers were made (Supplemental Table 3) for each BRGA group (Groups A, $\mathrm{C}-\mathrm{I})$ and to five ESTs possessing open reading frames with similarity to NBS-LRR proteins to determine if RGAs in

Table 3. Twenty-one bermudagrass-resistance gene analogs (BRGA) or expressed sequence tags (labeled "ES") containing similarity to disease-resistance genes or disease-resistance analogs that were segregating in the $\mathrm{T} 89 \times \mathrm{T} 574 \mathrm{~F}_{1}$ population.

\begin{tabular}{|c|c|c|c|c|}
\hline GenBank/BRGA & $\mathrm{cM}$ & $\begin{array}{c}\text { Left } \\
\text { marker }^{z}\end{array}$ & $\begin{array}{c}\text { Right } \\
\text { marker }^{z}\end{array}$ & $\begin{array}{c}\text { Map, } \\
\text { Linkage } \\
\text { group }\end{array}$ \\
\hline ES297666 & 7.9 & T5748B02b & T5741E11c & T89, 1a \\
\hline ES292682B & 31.1 & PCD068 & 一 & T89, 1a \\
\hline ES306149 & 29.1 & PCD128 & $\mathrm{T} 5741 \mathrm{C} 03 \mathrm{a}$ & T574, 1a \\
\hline ES304077 & 17.3 & T5745A04d & PAP07C04b & $\mathrm{T} 89,3 \mathrm{c}$ \\
\hline ES295859 & 8.7 & T5742D09 & PCD065a & $\mathrm{T} 89,4 \mathrm{c}$ \\
\hline ES302322 & 0 & - & T5742C08a & T89, 5a \\
\hline ES298588 & 39 & PAP03E08 & T5741G07 & Т89, 5a \\
\hline ES292682A & 17.7 & PCD137c & T5746B02b & T89, 6a \\
\hline BRGA208 & 37.6 & T5748F06a & RZ543b & T89, 12 \\
\hline ES304457-273 & 19 & $\mathrm{~T} 5741 \mathrm{H} 04 \mathrm{~b}$ & - & T89, 13 \\
\hline ES304457-268 & 24.6 & T5742G03A & BRGA229A & Т89, 19 \\
\hline BRGA229A & 45.5 & ES304457 & BRGA201 & Т89, 19 \\
\hline BRGA201 & 50.6 & BRGA229A & - & Т89, 19 \\
\hline ES299682B & 0 & - & T5743D12b & $\mathrm{T} 574^{\mathrm{y}}$ \\
\hline ES296578 & 0 & - & ES299276 & $\mathrm{T} 89^{\mathrm{y}, \mathrm{x}}$ \\
\hline ES299276 & 4.4 & ES296578 & - & T89 \\
\hline ES303684 & 15 & T5741E07c & ES303694 & $\mathrm{T} 89^{\mathrm{y}, \mathrm{w}}$ \\
\hline ES303694 & 30 & ES303684 & PCD108 & T89 $9^{\mathrm{y}, \mathrm{w}}$ \\
\hline ES307377 & & & & Unlinked \\
\hline BRGA229B & & & & Unlinked \\
\hline BRGA179 & & & & Unlinked \\
\hline
\end{tabular}

${ }^{\mathrm{z}}$ Left and right are markers that flank the EST or BRGA.

${ }^{\mathrm{y}}$ Markers found on this linkage group were not mapped by Bethel et al. (2006).

${ }^{x}$ These markers group together on a linkage group not previously identified by Bethel et al. (2006).

wThese markers group together on a linkage group not previously identified by Bethel et al. (2006). zoysiagrass, st. augustinegrass, seashore paspalum, bentgrass, and centipedegrass amplify. Seven primer pairs (BRGA131, BRGA167, BRGA173, BRGA179, ES304944, ES295859, and ES296552) amplified a product among turf genera, whereas six primer pairs (BRGA136, BRGA162, BRGA163, BRGA208, ES303684, and ES296578) failed to amplify a product among turf genera. Primer pairs designed from the ES296552 and ES295859 sequences amplified only in zoysiagrass cultivars, primer pairs designed from the ES304944 and BRGA179 sequences amplified only in st. augustinegrass cultivars, and primer pairs designed from the BRGA167 sequence amplified only seashore paspalum cultivars. Primer pairs designed from the BRGA173 sequence amplified only seashore paspalum and centipedegrass cultivars and primer pairs designed from the BRGA131 sequence amplified in st. augustinegrass, zoysiagrass, bentgrass, centipedegrass, and seashore paspalum cultivars. PCR products generated from cross-species amplifications were cloned and sequenced. Only primer pairs ES295859 and ES296552 amplified RGAs in the zoysiagrass cultivar Empire, whereas primer pair BRGA173 amplified a RGA from seashore paspalum cultivar Sea Isle 1 . The deduced amino acid sequence of these turfgrass-resistance gene analogs (TRGA) is shown in Supplemental Fig. 2 (see the online version of this article at ashs.org to view the figure). TRGA2 and TRGA3 contained the conserved motifs of the NBS (Supplemental Fig. 2, amino acids highlighted green), and when all three TRGA were compared with the bermudagrass sequence, shared regions of amino acid identity could be identified (Supplemental Fig. 2, amino acids not highlighted or highlighted green). The TRGA1 sequence spanned the end of the LRR motif to the C-terminal region of a NBS-LRR analog.

\section{Discussion}

Isolation of BRGA. Thirty-one unique BRGA and EST that formed nine groups were identified from diploid, triploid, tetraploid, and hexaploid bermudagrass using degenerate primers previously used to amplify RGAs in sunflower (Helianthus spp.), melon (Cucumis melo), soybean (Glycine max), and citrus (hybrid of Poncirus trifoliata and Citrus grandis) (Radwan et al., 2008; Brotman et al., 2002; Kanazin et al., 1996; Deng et al., 2000). Although it might be expected that more RGAs would be isolated from the hexaploid bermudagrass 'Tifton 10', as six homologous chromosomes are present, the most BRGA groups were amplified from triploid 'TifGrand'. This is likely due to preferential amplification of 'TifGrand' with the degenerate primer pairs used. In contrast, only one degenerate primer amplified BRGA from T574 (Table 2 ), as all other degenerate primers amplified retrotransposon or hypothetical protein analogs from T574. It is possible that the BRGA fragments from T574 are not $\approx 500 \mathrm{bp}$ and the incorrect fragment was captured or, alternatively, that the degenerate primers used (excluding PLP/antiHD1) do not have enough sequence similarity to amplify BRGA from T574.

The similarity of the amino acid sequence (68\% identity) spanning the P-loop to the HD domain between the Pit gene from rice and BRGA215 (Fig. 2) holds promise. The Pit gene confers race-specific resistance against $M$. grisea in rice (Hayashi and Yoshida, 2009). This fungus is the same fungus that causes gray leaf spot (blast) primarily on st. augustinegrass, but may also cause severe damage to turfgrasses in the genera Cynodon, Eremochloa, and Paspalum (Smiley et al., 1992). BRGA215 
would be a candidate RGA to test if linkage exists between BRGA215 and the gray leaf spot resistance gene in a bermudagrass population segregating for gray leaf spot resistance.

MAPPING OF BRGA. Although the polymorphism rate was high between the mapping population parents T89 and T574 (30 of 38 primer pairs amplified a polymorphic fragment), only seven primer pairs amplified RGA where the dominant allele was derived from T574 (Supplemental Table 2). This lack of amplification of T574 alleles could be because of the small number of BRGA amplified from T574 using degenerate primers and that the EST library was generated using the genotype T89. Of the 30 primer pairs that amplified polymorphic markers, only 21 markers were segregating in the $F_{1}$ mapping population (Supplemental Tables 2 and 3). The high percentage of non-segregating polymorphic markers could be due to the homozygosity of alleles in T574 or to the presence of the allele at three or all four homologous chromosomes in T89 causing all progeny to contain the allele, or possibly due to segregation distortion.

Of the 18 markers that could be placed on the T89 or T574 map (noting that the genetic map was created using single-dose restriction fragment mapping and necessitates the building of separate maps for each of the parental genomes), multiple BRGA or ESTs mapped on T89 linkage groups 1a and 5a and three markers with similarity to NBS-LRR proteins mapped to a 26-cM region on T89 linkage group 19. Furthermore, clustering of markers could be seen on linkage groups that were not previously identified (Table 3). ES296578 and ES299276, which have similarity to NBS-LRR, formed their own linkage group and are $4.4 \mathrm{cM}$ apart. ES303684 and ES303694, which have similarity to a NBS-LRR and a dirigent protein, respectively, form a linkage group of four markers. This clustering of RGA has been seen in many other plant species (Bakker et al., 2003; Brotman et al., 2002; Harris et al., 2009; McHale et al., 2006), and RGAs have been found to be linked to disease-resistance genes in several species (Brotman et al., 2002; Deng et al., 2000; Irigoyen et al., 2004; Kanazin et al., 1996; Xu et al., 2005).

Conservation of BRGA. Species within the grass family, Poaceae, contain genomes that are syntenic, i.e., the gene number and order are conserved (Gale and Devos, 1998). This synteny frequently does not extend to RGAs in rice, barley, and foxtail millet (Setaria spp.) and indicates a rapid evolution of resistance genes in each of these species (Leister et al., 1998). Many analogs were conserved across the three species, although this was not always the case (Leister et al., 1998). Although NBS-LRR loci frequently rearrange and evolve through recombination, unequal crossing-over, gene conversion, insertion-deletion, and point mutations (Radwan et al., 2008), and may have a rapid evolutionary rate compared with the rest of the monocot genome (Leister et al., 1998), three RGAs could be amplified from zoysiagrass or seashore paspalum using BRGA or EST primers. These RGA in zoysiagrass or seashore paspalum may map closely to resistance gene loci that are identified in these species. Furthermore, the amplification of RGA from turf species belonging to the subfamily Chloridoideae and Panicoideae indicates that these BRGA or ESTs were present in a common ancestor. Chloridoideae and Panicoideae subfamilies are thought to have diverged about 34.6 to 38.5 million years ago (Kim et al., 2009).

SSRs. Four unique clones with no similarity to BRGA contained SSRs (GU170365-GU170368) and may be useful in adding markers to the bermudagrass genetic map (Bethel et al., 2006) that could potentially link homologous linkage groups for the T89 genetic map and for comparative mapping with other grass species. SSR discovery has been limited in bermudagrass. Five SSR markers were identified in a bermudagrass genomic library study (Williams, 2003), and 10 chloroplast-specific SSR length polymorphisms were amplified in bermudagrass (Karaca et al., 2002). Also, 143 EST-SSRs that contained two- to fivenucleotide repeats of a minimum repeat length of five were identified from a bermudagrass EST study, but were not empirically tested (Kim et al., 2008). In many RGA studies, it is not uncommon that the majority of sequences generated have no similarity to RGA (Brotman et al., 2002; Chen et al., 2006; Glynn et al., 2008). Examination of these sequences for SSRs may be useful in many plant species for the generation of SSR markers in data that would likely be discarded.

In conclusion, in this study, nine groups of BRGA or ESTs were identified from diploid, triploid, tetraploid, and hexaploid bermudagrass that displayed disease resistance to a wide range of phytopathogens or were used to create the $F_{1}$ map. The NBS sequences examined contained non-TIR-NBS-LRR motifs, and the mapping of BRGA and ESTs identified regions where these markers cluster. The creation and placement of these markers on the bermudagrass genetic maps is an important step in the study of disease resistance in bermudagrass. Phenotyping a population segregating for a disease of interest and determination of whether these markers are linked to diseaseresistance genes are needed to use these markers for MAS.

\section{Literature Cited}

Baird, J.H., D.L. Martin, C.M. Taliaferro, M.E. Payton, and N.A. Tisserat. 1998. Bermudagrass resistance to spring dead spot caused by Ophiosphaerella herpotricha. Plant Dis. 82:771-774.

Bakker, E., P. Butterbach, J. Rouppe van der Voort, E. van der Vossen, J. van Vliet, J. Bakker, and A. Goverse. 2003. Genetic and physical mapping of homologues of the virus resistance gene $R x l$ and the cyst nematode resistance gene Gpa2 in potato. Theor. Appl. Genet. 106:1524-1531.

Bethel, C.M., E.B. Sciara, J.C. Estill, J.E. Bowers, W. Hanna, and A.H. Paterson. 2006. A framework linkage map of bermudagrass (Cynodon dactylon $\times$ transvaalensis) based on single-dose restriction fragments. Theor. Appl. Genet. 112:727-737.

Boutin-Ganache, I., M. Raposo, M. Raymond, and C.F. Deschepper. 2001. M13-tailed primers improve the readability and usability of microsatellite analyses performed with two different allele-sizing methods. Biotechniques 31:25-28.

Brodsky, L.I., A.V. Vasiliev, Y.L. Kalaidzidis, Y.S. Osipov, R.L. Tatuzov, and S.I. Feranchuk. 1992. GeneBee: The program package for biopolymer structure analysis. Dimacs 8:127-139.

Brotman, Y., L. Silberstein, I. Kovalski, C. Perin, C. Dogimont, M. Pitrat, J. Klingler, G.A. Thompson, and R. Perl-Treves. 2002. Resistance gene analogues in melon are linked to genetic loci conferring disease and pest resistance. Theor. Appl. Genet. 104: 1055-1063.

Burton, G.W. 1966. Registration of crop varieties: Tifdwarf bermudagrass. Crop Sci. 6:93-94.

Casler, M.D. 2006. Perennial grasses for turf, sport and amenity uses: Evolution of form, function and fitness for human benefit. J. Agr. Sci. 144:189-203.

Chang, N.T., B.R. Wiseman, R.E. Lynch, and D.H. Habeck. 1985. Fall armyworm (Lepidoptera: Noctuidae) orientation and preference for selected grasses. Fla. Entomol. 68:296-303.

Chen, Y., L. Long, X. Lin, W. Guo, and B. Liu. 2006. Isolation and characterization of a set of disease resistance-gene analogs (RGAs) 
from wild rice, Zizania latifolia Griseb. I. Introgression, copy number lability, sequence change, and DNA methylation alteration in several rice-Zizania introgression lines. Genome 49:150-158.

Collier, S.M. and P. Moffett. 2009. NB-LRRs work a "bait and switch" on pathogens. Trends Plant Sci. 14:521-529.

Crow, W.T. 2002. Nematode, where is thy sting? Golf Course Mgt. 70:103-106.

Deng, Z., S. Huang, P. Ling, C. Chen, C. Yu, C.A. Weber, G.A. Moore, and F.G. Gmitter. 2000. Cloning and characterization of NBS-LRR class resistance-gene candidate sequences in citrus. Theor. Appl. Genet. 101:814-822.

DeYoung, B.J. and R.W. Innes. 2006. Plant NBS-LRR proteins in pathogen sensing and host defense. Nat. Immunol. 7:1243-1249.

Drummond, A.J., B. Ashton, M. Cheung, J. Heled, M. Kearse, R. Moir, S. Stones-Havas, T. Thierer, and A. Wilson. 2009. Geneious v4.5. 18 Jan. 2010. <http://www.geneious.com>.

Gale, M.D. and K.M. Devos. 1998. Plant comparative genetics after 10 years. Science 282:656-659.

Gasteiger, E., A. Gattiker, C. Hoogland, I. Ivanyi, R.D. Appel, and A. Bairoch. 2003. ExPASy: The proteomics server for in-depth protein knowledge and analysis. Nucleic Acids Res. 31:3784-3788.

Giblin-Davis, R.M., J.L. Cisar, F.G. Bilz, and K.E. Williams. 1992. Host status of different bermudagrasses (Cynodon spp.) for the sting nematode, Belonolaimus longicausdatus. J. Nematol. 24:749756.

Glynn, N.C., J.C. Comstock, S.G. Sood, P.M. Dang, and J.X. Chaparro. 2008. Isolation of nucleotide binding site-leucine rich repeat and kinase resistance gene analogues from sugarcane ( $\mathrm{Sac}$ charum spp.). Pest Manag. Sci. 64:48-56.

Hanna, W.W. 1986. A bermudagrass primer and the Tifton bermudagrass. U.S. Golf Assn. Green Section Record 24:11-13.

Hanna, W.W., S.K. Braman, and B.M. Schwartz. 2010. 'ST5', a shadetolerant turf bermudagrass. HortScience 45:132-134.

Harris, K.R., W.P. Wechter, and A. Levi. 2009. Isolation, sequence analysis, and linkage mapping of NBS-LRR disease resistance gene analogs in watermelon. J. Amer. Soc. Hort. Sci. 134:649-657.

Hayashi, K. and H. Yoshida. 2009. Refunctionalization of the ancient rice blast disease resistance gene Pit by the recruitment of a retrotransposon as a promoter. Plant J. 57:413-425.

Hein, M.A. 1953. [Cynodon dactylon (L.) Pers.] Registration of varieties and strains of bermudagrass: II. Agron. J. 45:572-573.

Hein, M.A. 1961. [Cynodon dactylon (L.) Pers.] Registration of varieties and strains of bermudagrass: III. Agron. J. 53:276.

Irigoyen, M.L., Y. Loarce, A. Fominaya, and E. Ferrer. 2004. Isolation and mapping of resistance gene analogs from the Avena strigosa genome. Theor. Appl. Genet. 109:713-724.

Jukes, T.H. and C.R. Cantor. 1969. Evolution of protein molecules, p. 21-132. In: H.N. Munro (ed.). Mammalian protein metabolism. Academic Press, New York.

Kanazin, V., L.F. Marek, and R.C. Shoemaker. 1996. Resistance gene analogs are conserved and clustered in soybean. Proc. Natl. Acad. Sci. USA 93:11746-11750.

Karaca, M., S. Saha, A. Zipf, J. Jenkins, and D. Lang. 2002. Genetic diversity among forage bermudagrass (Cynodon spp.): Evidence from chloroplast and nuclear DNA fingerprinting. Crop Sci. 42: 2118-2127.

Kim, C., C.S. Jang, T.L. Kamps, J.S. Robertson, F.A. Feltus, and A.H. Paterson. 2008. Transcriptome analysis of leaf tissue from bermudagrass (Cynodon dactylon) using a normalized cDNA library. Funct. Plant Biol. 35:585-594.

Kim, C., H. Tang, and A.H. Paterson. 2009. Duplication and divergence of grass genomes: Integrating the chloridoids. Trop. Plant Biol. 2:51-62.

Leister, D., A. Ballvora, F. Salamini, and C. Gebhardt. 1996. A PCR-based approach for isolating pathogen resistance genes from potato with potential for wide application in plants. Nat. Genet. $14: 421-429$.
Leister, D., J. Kurth, D.A. Laurie, M. Yano, T. Sasaki, K. Devos, A. Graner, and P. Schultze-Lefert. 1998. Rapid reorganization of resistance gene analogues in cereal genomes. Proc. Natl. Acad. Sci. USA 95:370-375.

McHale, L., X. Tan, P. Koehl, and R.W. Michelmore. 2006. Plant NBS-LRR proteins: Adaptable guards. Genome Biol. 7:212.

McHughen, A. and S. Smyth. 2008. U.S. regulatory system for genetically modified [genetically modified organism (GMO), rDNA or transgenic] crop cultivars. Plant Biotechnol. J. 6:2-12.

Meyers, B.C., A.W. Dickerman, R.W. Michelmore, S. Sivaramakrishnan, B.W. Sobral, and N.D. Young. 1999. Plant disease resistance genes encode members of an ancient and diverse protein family within the nucleotide-binding superfamily. Plant J. 20:317-332.

National Center for Biotechnology Information. 2009. VecScreen. 12 Aug. 2009. <http://www.ncbi.nlm.nih.gov/VecScreen/VecScreen. html>.

Oosumi, T., D.R. Rockhold, M.M. Maccree, K.L. Deahl, K.F. McCue, and W.R. Belknap. 2009. Gene Rbpi-bt1 from Solanum bulbocastanum confers resistance to late blight in transgenic potatoes. Amer. J. Potato Res. 86:456-465.

Pratt, R.G. 2003. An excised-leaf inoculation technique for evaluating host-pathogen interactions and quantitative resistance of bermudagrass genotypes to dematiaceous hyphomycetes. Phytopathology 93:1565-1571.

Radwan, O., S. Gandhi, A. Heesacker, B. Whitaker, C. Taylor, A. Plocik, R. Kesseli, A. Kozik, R.W. Michelmore, and S.J. Knapp. 2008. Genetic diversity and genomic distribution of homologs encoding NBS-LRR disease resistance proteins in sunflower. Mol. Genet. Genomics 280:111-125.

Redenbaugh, K. and A. McHughen. 2004. Regulatory challenges reduce opportunities for horticultural biotechnology, California Agr. 58:106. 18 Jan. 2010. <http://ucce.ucdavis.edu/files/repositoryfiles/ ca5802p106-69110.pdf>.

Reinert, J.A. 2009. Highlights and impacts of FY '05 projects funded by the Texas imported fire ant research and management project. 18 Jan. 2010. <http://fireant.tamu.edu/research/projects/ pdf/Identification $\% 20$ and $\% 20$ Development $\% 20$ of $\% 20$ grasses. pdf $>$.

Reinert, J.A. and P. Busey. 2001. Host resistance to tawny mole cricket, Scapteriscus vicinus, in bermudagrass, Cynodon spp. Intl. Turfgrass Soc. Res. J. 9:793-797.

Sawahel, W.A. 1994. Transgenic plants: Performance, release and containment. World J. Microbiol. Biotechnol. 10:139-144.

Shortman, S.L., S.K. Braman, R.R. Duncan, W.W. Hanna, and M.C. Engelke. 2002. Evaluation of turfgrass species and cultivars for potential resistance to twolined spittlebug (Hemiptera:Cercopidae). J. Econ. Entomol. 95:478-486.

Smiley, R.W., P.H. Dernoeden, and B.B. Clarke. 1992. Compendium of turfgrass diseases. 2nd ed. Amer. Phytopathol. Soc, St. Paul, MN. Taliaferro, C.M. 1995. Diversity and vulnerability of bermuda turfgrass species. Crop Sci. 35:327-332.

Taliaferro, C.M. 2003. Bermudagrass (Cynodon (L.) Rich), p. 235256. In: M.D. Casler and R.R. Duncas (eds.). Turfgrass biology, genetics, and breeding. Wiley, Hoboken, NJ.

Van der Vossen, E., A. Sikkema, B.L. Hekkert, J. Gros, P. Stevens, M. Muskens, D. Wouters, A. Pereira, W. Stiekema, and S. Allefs. 2003. An ancient R gene from wild potato species Solanum bulbocastanum confers broad-spectrum resistance to Phytophthora infestans in cultivated potato and tomato. Plant J. 36:867-882.

Van Ooijen, J.W. 2006. Joinmap 4. Software for the calculation of genetic linkage maps in experimental populations. Kyazma, Wageningen, The Netherlands.

Webster, T.M., C.W. Bednarz, and W.W. Hanna. 2003. Sensitivity of triploid hybrid bermudagrass cultivars and common bermudagrass to postemergence herbicides. Weed Technol. 17:509-515.

Webster, T.M., W. Hanna, and B.G. Mullinix. 2004. Bermudagrass (Cynodon spp.) dose-response relationships with clethodim, glufosinate and glyphosate. Pest Manag. Sci. 60:1237-1244. 
White, R.H. and R. Dickens. 1984. Plant-parasitic nematode populations in bermudagrass as influenced by cultural practices. Agron. J. $76: 41-43$

Wiecko, G. 2007. Management of tropical turfgrasses, p. 116-137. In: M. Pessarakli (ed.). Handbook of turfgrass management and physiology. CRC Press, Boca Raton, FL.

Williams, N.R. 2003. PCR-based polymorphism in bermudagrass (Cynodon spp.). MS Thesis, Univ. Florida, Gainesville.
Xu, Q., X. Wen, and X. Deng. 2005. Isolation of TIR and nonTIR NBS-LRR resistance gene analogues and identification of molecular markers linked to a powdery mildew resistance locus in chestnut rose (Rosa roxburghii Tratt). Theor. Appl. Genet. 111:819830.

$\mathrm{Xu}$, Y. and J.H. Couch. 2008. Marker-assisted selection in plant breeding: From publications to practice. Crop Sci. 48:391407. 
Supplemental Table 1. Bermudagrass expressed sequence tags (EST) with BLASTx homology to resistance genes or resistance gene analogs (the top BLASTx hit, including GenBank accession, organism, and e-value, is shown for each EST query) that were used for cross-species amplification or were polymorphic between $\mathrm{T} 89$ and $\mathrm{T} 574$, the parents of the $\mathrm{F}_{1}$ genetic mapping population.

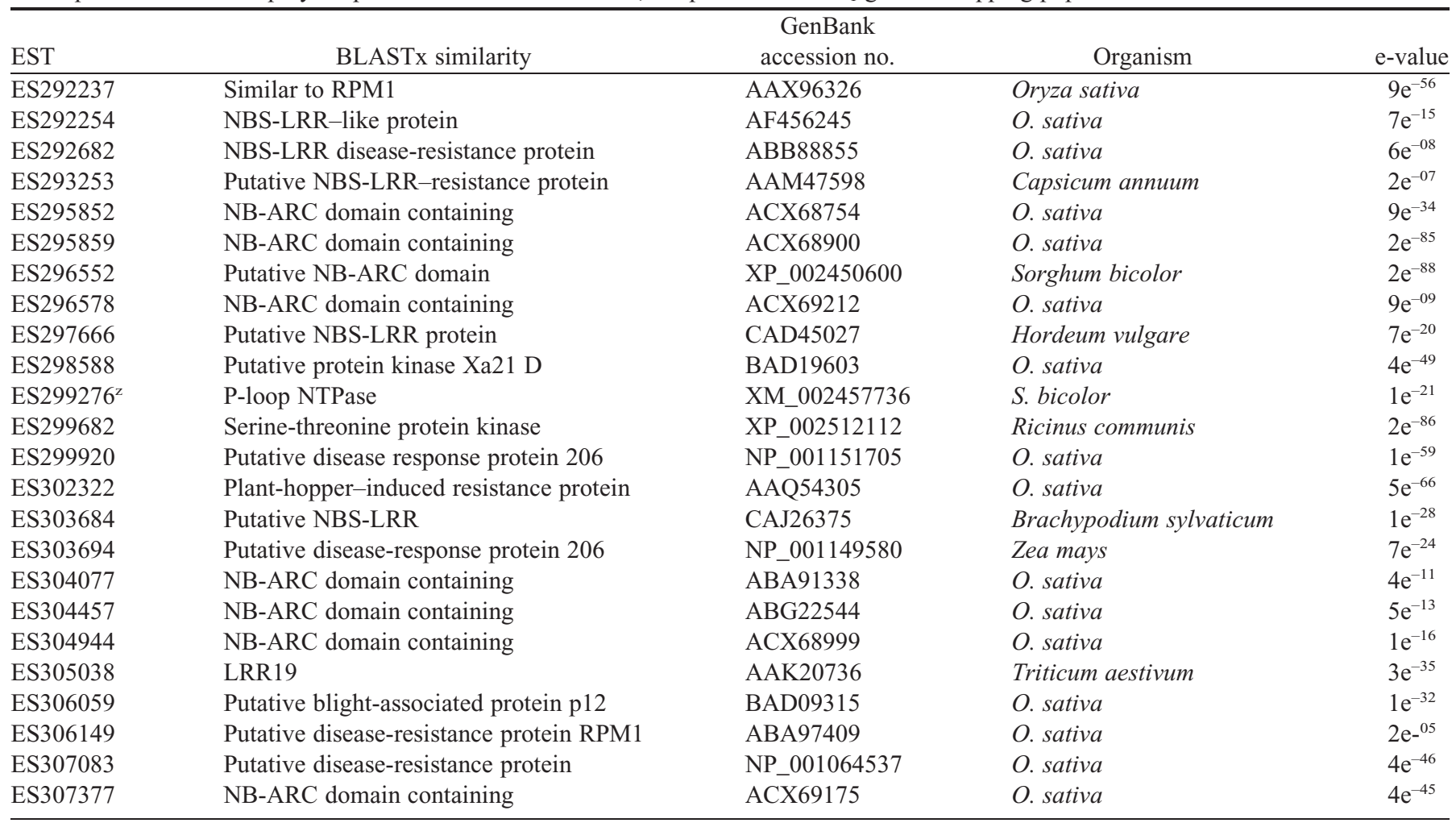

zTblastx hit, as no similarity to other GenBank accessions was seen using BLASTn or BLASTx.

Supplemental Table 2 . Sequences of 30 primer pairs used to generate 34 polymorphic markers used for genetic mapping in a $\mathrm{T} 89 \times \mathrm{T} 574 \mathrm{~F}_{1}$ cross (Cynodon dactylon $\times$ C. transvaalensis).

\begin{tabular}{|c|c|c|c|c|}
\hline Primer & Sequence & $\mathrm{Ta}\left({ }^{\circ} \mathrm{C}\right)^{\mathrm{z}}$ & $\begin{array}{c}\text { Amplicon size (bp) } \\
\text { (nondigested, digested) } \\
\text { (-Dominant parent) }\end{array}$ & $\mathrm{SEG}^{\mathrm{y}}$ \\
\hline BRGA38-F & M13-AATCTAGCGTTCCCTGACGA & 50 & $151^{\mathrm{w}}, 50-\mathrm{T} 574$ & No \\
\hline BRGA38-R & AGGTCCATGCTTCAGACGAC & & & \\
\hline BRGA81-F & M13-GCATTGGCAGAGCATGTAAA & 56.7 & $156-\mathrm{T} 574$ & No \\
\hline BRGA81-R & TCGCGTGGTTATTGTGATGT & & & \\
\hline BRGA131-F & TTTCGAAGCTGCTGTTGTTG & 63.4 & $375-\mathrm{T} 89$ & No \\
\hline BRGA131-R & GCGACCAACTCTGTTTGCTC & & & \\
\hline BRGA163-F & TGGCTGTGTGTGACAGATGA & 45 & $402-\mathrm{T} 89$ & No \\
\hline BRGA163-R & ACACТТСССААТTТССАССА & & & \\
\hline BRGA167-F & CGCTTGGGCAGGTAGTGTAT & 45 & $500^{\mathrm{w}}, 400-\mathrm{T} 574$ & No \\
\hline BRGA167-R & TCTCAACAAATGCTGCTTGC & & & \\
\hline BRGA179-F & GCATGGCTTTGTGTTTCTCA & 45 & 328-T89 & Yes \\
\hline BRGA179-R & ACAGCTCCCATCCTACATCG & & & \\
\hline BRGA201-F & M13-GGACCATATGCATCGTGTTG & 63.4 & 124-T89 & Yes \\
\hline BRGA201-R & GGCCTGAAGATGTTGCACTT & & & \\
\hline BRGA208-F & CATGAGCAGAGGATACAGGAGA & 45 & $367^{\mathrm{w}}, 300-\mathrm{T} 89$ & Yes \\
\hline BRGA208-R & TCAACAGGTCTAGGCCATCC & & & \\
\hline BRGA229-F & M13-GCTGCAGCCACAGGAATAAT & 45 & $108-\mathrm{T} 574,126-\mathrm{T} 89$ & Yes $^{v}$ \\
\hline BRGA229-R & TCCTATGACCACCGACATCA & & & \\
\hline ES292237-F & M13- AGCTCAGGGAACTGGTCTCA & 64.6 & $160-\mathrm{T} 89$ & No \\
\hline ES292237-R & GGGTCAATGGTTTCAGCACT & & & \\
\hline ES292682-F & M13-GGTGGCTAGGCTTGGTATGA & 50 & $122,140-\mathrm{T} 89$ & Yes $^{\mathrm{v}}$ \\
\hline ES292682-R & CACCCAGGTCATGGTAGCTT & & & \\
\hline
\end{tabular}




\begin{tabular}{|c|c|c|c|c|}
\hline Primer & Sequence & $\mathrm{Ta}\left({ }^{\circ} \mathrm{C}\right)^{\mathrm{z}}$ & $\begin{array}{c}\text { Amplicon size (bp) } \\
\text { (nondigested, digested) } \\
\text { (-Dominant parent) }\end{array}$ & $\mathrm{SEG}^{\mathrm{y}}$ \\
\hline$\overline{\text { ES293253-F }}$ & M13-AGAGCTGTGGAGGCACACTT & 45 & $150^{\mathrm{u}}, 148-\mathrm{T} 89$ & No \\
\hline ES293253-R & TCCTCAAGCCTAGGCGTACT & & & \\
\hline ES295859-F & M13-ACCAAACTGGTTCCCATTGC & 45 & 94-T89 & Yes \\
\hline ES295859-R & GTCTTCCGTGGCACTTAGTTCAG & & & \\
\hline ES296552-F & M13-GTGGTAAATCTTGCCCAATCAAC & 63.2 & 96-T89 & No \\
\hline ES296552-R & GCAGAAGAGGGTAAATGCATCAC & & & \\
\hline ES296578-F & AGTACCCAGCCCAGTCACAG & 45 & $576-\mathrm{T} 89$ & Yes \\
\hline ES296578-R & CACGTGTCAACAGGTGATCC & & & \\
\hline ES297666-F & M13- GCAGGTCCATCGACTGAAAT & 45 & $126-\mathrm{T} 89$ & Yes \\
\hline ES297666-R & GCCGGCAAAAATATCAAGAA & & & \\
\hline ES298588-F & M13-CCCCCGAAATAGGTTTCTTC & 50 & 134-T89 & Yes \\
\hline ES298588-R & AAGCAGGATTTGCTGCACTT & & & \\
\hline ES299276-F & M13- CGAGCTTTCGTCTTCGTAGG & 50 & $146-\mathrm{T} 89$ & Yes \\
\hline ES299276-R & TGTTCGATGCTGGAGATGAG & & & \\
\hline ES299682-F & M13-CAAGATGTGCTTCCACCAGA & 50 & $158^{\mathrm{w}}, 156-\mathrm{T} 574$ & Yes $^{t}$ \\
\hline ES299682-R & GCCAGTAACCGATTTTCAT & & $156^{\mathrm{w}}, 154-\mathrm{T} 89$ & \\
\hline ES299920-F & M13-ACCTACATGCTGGGGTCCAT & 40 & $260-\mathrm{T} 574$ & No \\
\hline ES299920-R & СТCTAACCTCCTCCGACGTG & & & \\
\hline ES302322-F & M13-CTCCGCATCTACCTCGAGTC & 45 & 148-T89 & Yes \\
\hline ES302322-R & GAGAGCCACATGCTGTTTCA & & & \\
\hline ES303684-F & GGGGTCATTTGCGTGTACTT & 45 & $523-\mathrm{T} 89$ & Yes \\
\hline ES303684-R & CCСATCTCTTCAAAGCTTGC & & & \\
\hline ES303694-F & M13-AGCTCCTCCTGCCTTCTCAT & 61.8 & 122-T89 & Yes \\
\hline ES303694-R & GTAGTGCTCGTGTCGTCAGC & & & \\
\hline ES304077-F & M13-GTTGGGCAAGACCACTTGTT & 50 & $150-\mathrm{T} 89$ & Yes \\
\hline ES304077-R & CCAATCGTTTGGGTCTGAAC & & & \\
\hline ES304457-F & M13-ТСССТТСАТССТСАССАAАG & 50 & $268,270-\mathrm{T} 89$ & Yes $^{\mathrm{v}}$ \\
\hline ES304457-R & CAGAAGCTCTATCGCCTCGT & & & \\
\hline ES305038-F & M13-GGTTTGGCGTCACTTAGCTC & 50 & 130-T89 & No \\
\hline ES305038-R & GCСТCCACCATACСТСТCAA & & & \\
\hline ES306059-F & M13-GTTCACTGTGATGGCACTGG & 50 & 167-T89 & No \\
\hline ES306059-R & CGTGGTGCTTTTGTCACTGT & & & \\
\hline ES306149-F & M13-AGGAAAAATGGGTTCGAAGG & 50 & 138-T574 & Yes \\
\hline ES306149-R & TAATATGGCAGGCGATTTCC & & & \\
\hline ES307083-F & M13-GGGTACACGCTCAGCAAGAT & 66.8 & $122-\mathrm{T} 89$ & No \\
\hline ES307083-R & GCAAGAGTTGAGACGGGTTC & & & \\
\hline ES307377-F & M13-AACGGTGTCGGAAAGACAAC & 61.8 & 129-T89 & Yes \\
\hline ES307377-R & TCCATTTGTCGTGATCGTGT & & & \\
\hline
\end{tabular}

${ }^{\mathrm{z}}$ Ta was the annealing temperature used.

${ }^{y} \mathrm{SEG}$ was whether the polymorphic marker was segregating in the $\mathrm{F}_{1}$ population.

${ }^{x}$ Forward primers were labeled with a 5' M13 Tag (TGTAAAACGACGGCCAGT) where indicated (M13) and were resolved on 6.5\% acrylamide gels on a LI-COR® Biosciences 4300 DNA Analyzer (LI-COR, Lincoln, NE). Those primers without M13 labels were resolved on $1 \%$ agarose gels.

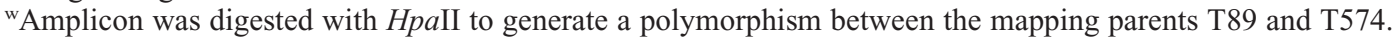

${ }^{\vee}$ Both amplicons from T89 were segregating.

"Amplicon was digested with EcoRV to generate a polymorphism between the mapping parents T89 and T574.

${ }^{t}$ Only the $\mathrm{T} 574$ band segregated in the $\mathrm{F}_{1}$ population. 
Supplemental Table 3. Primers designed from the eight bermudagrass-resistance gene analogs (BRGA) groups and five expressed sequence tags (ESTs) with similarity to nucleotide binding site-leucine-rich repeat (NBS-LRR) proteins for cross genera amplification.

\begin{tabular}{|c|c|c|}
\hline Primer & Sequence & $\begin{array}{c}\text { Size of } \\
\text { amplicon }(\mathrm{bp})^{\mathrm{z}}\end{array}$ \\
\hline BRGA131R & GCGACCAACTCTGTTTGCTC & \\
\hline BRGA136R & GGCATTTCTTGAGCATACTGG & \\
\hline BRGA162F & ACTTCAGAGCCACCGATGTT & 393 \\
\hline BRGA162R & TGACGACACACTTACCGATCA & \\
\hline BRGA163R & ACACTTCССААТTTCCACCA & \\
\hline BRGA167F & CGCTTGGGCAGGTAGTGTAT & 411 \\
\hline BRGA167R & TCTCAACAAATGCTGCTTGC & \\
\hline BRGA173F & GCCGGAAAAGGTTCCTACTT & 257 \\
\hline BRGA173R & TGTTTGCTCTTGCACTCCTC & \\
\hline BRGA179F & GCATGGCTTTGTGTTTCTCA & 328 \\
\hline ES295859R & AGAGCCCCTTCATGAAACCT & \\
\hline ES296552F & AGTACCCAGCCCAGTCACAG & 576 \\
\hline ES296552R & CACGTGTCAACAGGTGATCC & \\
\hline ES296578F & GCTCCATCTTGGACTTGGAC & 587 \\
\hline ES296578R & CTTTGTGTCGGTGTCGCTAA & \\
\hline ES303684F & GGGGTCATTTGCGTGTACTT & 523 \\
\hline ES303684R & CCCATCTCTTCAAAGCTTGC & \\
\hline ES304944F & ATCGCAAACACCGAGCTATT & 510 \\
\hline ES304944R & TCTTGTCCTCGAACATGCTG & \\
\hline
\end{tabular}

${ }^{\mathrm{z}}$ The annealing temperature used to amplify these fragments among the turf genera was $45^{\circ} \mathrm{C}$. 


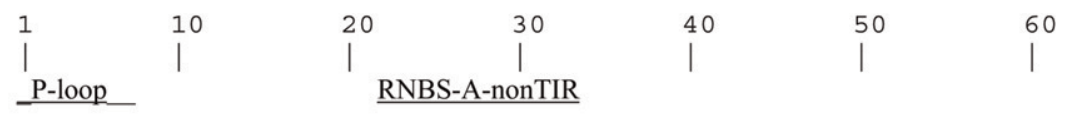

\begin{tabular}{|c|c|c|c|}
\hline BRGA172 & 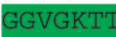 & TLAKMVYNDPRVQKH & EVTTIMRSVIE-LG------ - T \\
\hline BRGA161 & & ILAKMVYNDPRVQK & EVTTIMRSVIE-LG---- - - TNERC \\
\hline BRGA168 & & ILAEMVYNDCRVQK & EATTIMRSVIE-LG----- - TNERC \\
\hline GA131 & & TAKMVYNDSRVQ & EAAVVVRSVIE-L----- - ATNGRC \\
\hline RGA162 & & TLAEMVYNDCRVQ & RATDVVRSI IELA-------TVEPC \\
\hline RGA163 & & ILAKVVYNDCRVQQ & SVSGLVRSIVELA------ - TKKPC \\
\hline A167 & & ILGQVVYTDSRVV & DVKNITRKIITSL------ - TRSCC \\
\hline BRGA132 & & ILGQVVYADSRV & DVKNITRKIITSL------- - TRSCC \\
\hline RGA169 & & ILGQVVYADSRV & DVKNITRKIITSL------ - TRSCC \\
\hline RGA179 & & ILAQKVYNDNKI & SVVSLLKELLRNIG--------ADY \\
\hline RGA208 & & ILAQKIYHEQRIC & TEIDLLKQAIRMAG-------- GSY \\
\hline RGA211 & & ILAQKIYHEQRIC & TEIDLLKQAIRMAG-------- GSY \\
\hline RGA202 & & ILAQKIYHEQR & TEIDLLKQAIRMAG-------- GSC \\
\hline BRGA216 & & ILAQKIYHEQRIQ & TEIDLLKQEIRMAG-------- GSY \\
\hline BRGA136 & & TLVTRLYKEV - A & TINDLLRKILKELGCNSRASCSNAKT \\
\hline BRGA6 6 & & TFVTRLYKEV-AT & TINDLLRKILKELGSNSRASPSNTKT \\
\hline BRGA14 7 & & TFVTRLYKEV-AT & TINDLLRKILKELGSNSRASSSNTKT \\
\hline BRGA153 & & TFVTRLYKEV-A & TINDLLRKILKELGSNSRASSSNTKT \\
\hline BRGA6 7 & & TFVTRLYKEV-A & TIDDLLRKILKELGSNSRASSSNTKT \\
\hline BRGA182 & GVGK & ILVTRLYKEV - A' & TINDLLRKILKELGCNSRASCPNAKT \\
\hline BRGA186 & 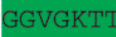 & ILVTRLYKEV - A & TINDLLRKILKELGCNSRASCSNAKT \\
\hline BRGA184 & $1+1$ & ILVTRLYKEV-AT & TINDLLRKILKELGCNSRASCSNAKT \\
\hline BRGA185 & & ILVTRLYKEV-AT & TINDLLRKILKELGCNSRASCSNAKT \\
\hline BRGA2 21 & & TLVTRLYKEV-AT & TINDLLRKILKELGCNSRASCSNAKT \\
\hline BRGA149 & GKT & ILVTRLYKEV-AT & TINDLLRKILKELGCNSSASCSNAKT \\
\hline BRGA34 & GGVGKT & TLVTRLYKEV-AT & TISDLLRKILKELGCNSSASCSNAKT \\
\hline BRGA33 & GGVGKTI & ILVTRLYKEV-ATSH & TINDLLRKILKELGCNSRASCSNAKT \\
\hline BRGA31 & GGVGKTI & ILVTRLYKEV-AT & TINDLLRKILKELGCNSRASCSNAKT \\
\hline BRGA79 & GGVGKTI & ILVTRLYKEV-AT & TINDLLRKILKELGCNSRASCSNAKT \\
\hline BRGA181 & GGVGKT & ILVTRLYKEV-AT & TINDLLRKILKELGCNSRASCSNAKT \\
\hline BRGA238 & GGRGKTI & ILVTRLYKEV-AT & TINDLLRKILKELGCNSRASCSNAKT \\
\hline
\end{tabular}

BRGA172 BRGA161 BRGA168 BRGA131 BRGA162 BRGA163 BRGA167 BRGA132 BRGA169 BRGA179 BRGA2 08 BRGA211 BRGA2 02 BRGA216 BRGA136 BRGA6 6 BRGA14 7 BRGA153 BRGA 67 BRGA182 BRGA186 BRGA184 BRGA185 BRGA221 BRGA14 9 BRGA3 4 BRGA33 BRGA 31 BRGA79 BRGA181 BRGA2 38

Kinase-2

RNBS-B

\begin{tabular}{|c|c|}
\hline & \\
\hline DNIEMLKGRLQET & \\
\hline & \\
\hline & \\
\hline & \\
\hline 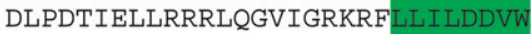 & \\
\hline LTDRIELLHSY & NNEEEQKWEDLRP \\
\hline HIQD-GGLQGA & YWELLCMPLLA \\
\hline HIQD-GGLQGALVI & WELL \\
\hline RHIQD-GGLQGALVI & NNERRDYWELLC \\
\hline QQDETAGELTKKLATAVEN & -VWTNILR---T \\
\hline DQLEAKSELLLRLMDTVTG & NKSD- - VWNKLLQ- - -M \\
\hline DQLEAKSELLLRLMDTVTG & NKSD- - VWNKLLQ- - -M \\
\hline DQLEAKSELLMRLMDTVSG & NKSD - -VWNELLQ- - - TPF \\
\hline DQLEAKSELLLRLMDTVSG & NKSD- - VWNELLQ- - -TPF \\
\hline DTDTDYRSLMEAVQGHLFQ & NDPH - - LWGKLLN- - LAFP \\
\hline DTDTDYRSLMEAVQGHLFK & -LWGKLLN- - LAFP \\
\hline DTDTDYRSLMEAVQG & - - LWGKLLN- - LAFPI \\
\hline DTDTDYRSLMEAVQG] & - -LWGKLLN- -LAFP \\
\hline DTDTDYRSLMEAVQG & - - LWGKLLN - - LAFPI \\
\hline DTDTDYRWLMEAIQG & - LWGKILN- - LAFPI \\
\hline DTDTDYRWLMEAIQGHLFR & - LWGKILN- - LAFPI \\
\hline DTDTDYRWLMEAIQGHLFR. & - LWGKILN- - LAFPI \\
\hline DTDTDYRWLMEAIQGHLFR & - LWGKILN- - LAFPD \\
\hline DTDTDYRWLMEAIQGHLFR & - - LWGKILN- - LAFPD \\
\hline DTDTDYRSLMEAVQGHLFK & - -LWGKILN- - LAFPD \\
\hline DTDTDYRSLMEAVQGHLFK & - - LWSKILN- - LAFPDI \\
\hline DTDTDYRSLMEAVQGHLFQR & - - LWGKILN - - LAFPDI \\
\hline DTDTDYRSLMEAVQGHLFQR & - - LWGKILN- - LAFPDI \\
\hline DTDTDYRSLMEAVQGHLFQR & - - LWGKILN- - LAFPDI \\
\hline DTDTDYRSLMEAVQGHLFQR & - LWGKILN- - LAFPD \\
\hline & ILN- - I \\
\hline
\end{tabular}

Supplemental Fig. 1. Deduced amino acid alignment of 31 bermudagrass-resistance gene analogs (BRGA) that contain nucleotide binding site-leucine-rich repeats. Motifs are highlighted and named as indicated at the top of the sequence. $\mathrm{HD}=$ hydrophobic domain, TIR-Toll, and mammalian interleukin-1 receptor. 
BRGA172 BRGA161 BRGA168 BRGA131 BRGA162 BRGA163 BRGA167 BRGA132 BRGA169 BRGA179 BRGA2 08 BRGA211 BRGA2 02 BRGA216 BRGA136 BRGA6 6 BRGA14 7 BRGA153 BRGA 67 BRGA1 82 BRGA186 BRGA184 BRGA185 BRGA2 21 BRGA14 9 BRGA3 4 BRGA33 BRGA31 BRGA79 BRGA181 BRGA2 38
QQVASIMGTLPHHELKILSEEESWKLFSMKAFANRGVQE-QTELVSTSKRIVNNCKG: QQVAS IMGTLPHHELKILSEEESWKLFSMKAFANRGVQE-QTELVSTSKRIVNNCKG:QQVAS IMGTLPHHELKILSEEESWKLFSMKAFANRGVQE-QTELVSTSKRIVNNCKG. QQVATIMGTVPHHNLKILTEEESRQLFSTKAFANRVQEQ- - TELVAIGKRIVNKCK RQVAS IMGTLPLYELACLSEHESWELFSKKAFNRLQKQ- - -DELILIGKCVVNMCKC EQVAS IMGTLPSHMISYLNQDDSWELFRKKAFCREEDEQ- - PKLVEIGKCIVKKCK KVVARLVQTMPFYNLKCLGPDDSWSLFKQAAFVEKGIAT - PVNLMNIGRS ITEKCK KVVARLVQTMPFYNLKCLGPDDSWSLFKQAAFVEKGIAT-PVNFVNIGRS ITEKCK KVVARLVQTMPFYNLKCLGPDDSWSLFKQAAFVEKGIAT - PVNFVSIGRS ITEKCK DTVARAIGVEDVHRVELMSNDVGWELLWKS - -MNISKETDVQNLRGIGMDIVRMCG LDVLGQMHAKYTHKVNQINITDGLDLLMERSFR - - PDEQIDDGFRDVGRQIVQKCD LDVLGQMHAKYTHKVNQINITDGLDLLIKRSFR - PDEQIDDGFRDVGRQIVQKCD LDVLGQMHAKYTHKVNKMNITDGLDLLIRRSFR - - PDEQINDGFRDVGRQIVQKCD LDVLGQMHAKYTHKVNKINITDGLDLLIKRSFR - - PDEQINDGFRNVGRQIVQKCD NEVAKAATRERTMMLEPLQSSEAWTLFCNITFRDI PNRTCPTHLEELATSMLKKCHC SNEVAKAATRERTMMLEPLQSSEAWTLFCNITFRDI PNRTCPTHLEELATSMLKGCH SNEVAKAATRERTMMLEPLQSSEAWTLFCNITFRDI PNRTCPTHLEELATSMLKRCH SNEVAKAATRERTMMLEPLQSSEAWTLFCNITFRDI PNRTCPTHLEEIATSMLKRCH SNEVAKAATRERTMMLEPLQSSEAWTLFCNITFRDI PNRACPTHLEELATSMLKRCH NEVAKAATRERIMMLEPLQLSEAWTLFCNITFRDVPNRTCPSHLEELATSMLKRCH NEVAKAATRERIMMLEPLQLSEAWTLFCNITFRDVPNRTCPSHLEELATSMLKRCH SNEVAKAATRERIMMLEPLQLSEAWTLFCNITFRDVPNRTCPSHLEELATSMLKRCH SNEVAKAATRERIMMLEPLQLSEAWTLFCNITFRDVPNRTCPSHLEELATSMLKRCHC SNEVAKAATRERIMMLEPLQLSEAWTLFCNITFRDVPNRTCPSHLEELATSMLKRCHC SNEVAKAATRERIMMLEPLQLSGAWTLFCNITFRDVPNRTCPSHLEELATSMLKRCH NEVAKAATRERIMMLESLQLSEAWTLFCNITLRDVPNRTCPSHLEELATSMLKRCHC SNEVAKAATRERIMMLEPLQLSEAWTLFCNITFRDVPNRTCPSHLEELATSMLKRCH SNEVAKAATRERIMMLEPLQLSEAWTLFCNITFRDVPNRTCPSHLEELATSMLKRCH SNEVAKAATRERIMMLEPLQLSEAWTLFCNITFRDVPNRTRPSHLEELATSMLKRCH NEVAKAATRERIMMLEPLQLSEAWTLFCNITFRDVPNRTCPSHLEELATSMLKRCH SNEVAKAATRERIMMLEPLQLCEAWTLFCNITFRDVPNRTCPSHLEELATSMLKRCH

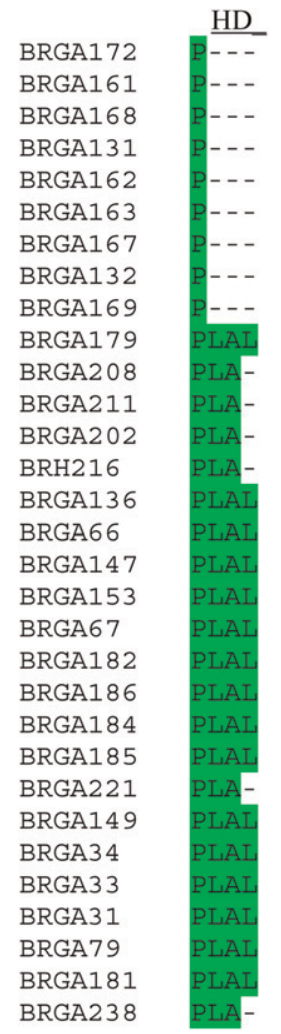

Supplemental Fig. 1. (Continued). 


\begin{tabular}{|c|c|c|c|c|c|}
\hline TRGA Primer & Genotyp & analog (BLASTx) & Accession & Organism & e-value \\
\hline TRGA1 ES295859 & Empire & putative disease resistance protein & BAC15497 & Oryza sativa & $6 \mathrm{e}^{-76}$ \\
\hline TRGA2 ES296552 & Empire & putative NBS-LRR protein & ACD70335 & Saccharum arunaceum & $7 e^{-69}$ \\
\hline TRGA3 BRGA173 & SI1 & NBS-LRR like protein & ABW04965 & Eleusine coracana & $5 \mathrm{e}^{-24}$ \\
\hline
\end{tabular}

$\begin{array}{ll}\text { TRGA1 } & \text { GITNLPNLVNLLAGKRCYHHNGLWPISEFWGLHVPKKLGNLDALRTLAQVAFTESTTQFI } \\ \text { ES295859 } & \text { GITNLPNLVLLAGKRYYNHNGLWPMSEFWGLYVPKKLGNLDALRTLAQVAFTESTTQSI } \\ \text { TRGA1 } & \text { SELGKLPRLNKLGVMMFVDDDSSWASLISALENLSGNLCSLLLWRPDGVMNFACLDSLSR } \\ \text { ES295859 } & \text { SELGKLSGLRKLGVMMFVDDDNSWASLISALGNLSGNLCSLLLWRPDGAMNYDCLNSLSR } \\ \text { TRGA1 } & \text { PSMFMKSINFRGQLIKLPKWFPLLSNLTELTLRATELSATEDLRVLARLPSLLYLRLHHS } \\ \text { ES295859 } & \text { PPMFMKSINFRGQLRLPNWFPLLSNLTELTLRATELSATEDLKVLARLPSLLYLRLHHS } \\ \text { TRGA1 } & \text { AFVHTEFSVAASEFPCLKLLVIHLATHEPWRARFHEGA } \\ \text { ES295859 } & \text { AYVQPEFAVAALDFPRLKLLVIHLALFQTWTARFHEGA }\end{array}$

Kinase-2

RNBS-B

TRGA2

ES296552 -YPAQSQLADLDADDLKKEI KKRVADGKCLLVLDDVWDKEAFHRISDALQNLQATRVIIT
EYPAQSQLADLDAEDLKVKI TEKLTAGKCLLVLDDVWSQEAFLQIRDTLQNLQASRVIT

TRGA2

ES296552 TRQEHVATLAQPTRQLKLKPLEHSDAFSLFCRKAFYNSMESKCP PELEKLLANNIVG̈KCQG
TRQEHVVNLAQSTHQLRLKPLERSDAFTLFCKKAFCNRMEHRCPQDLENLANNVVDKCRG

TRGA2

ES296552 HD
LPLAIVSIAGMLSSLPQKEYVWNEMYMOLRSELANDNHVSAILNLSYHDLSGELRNCFLY
LPLAIVSIGGMLSSLPPTEYVWSEMYKQLRGELANDNHVSAILNLSYHDLSGELRNCFLY

TRGA2

ES296552

RNBS-D-NonTIR

CSLFPEDHLLTR

Kinase-2

RNBS - B

TRGA3

BRGA173

RKRF LLMXDDVWNEDQNKWEEDLRPLLCSSIGGLGSMIVVTSRSRQVAEIMGTLPPHELV

TRGA3

BRGA173

CLSEDDSWELFSKKXFS-RGVQEQT
ILSEEESWKLFSMKAFAnRGVQEQT

Supplemental Fig. 2. Turfgrass-resistance gene analogs (TRGA) successfully amplified from zoysiagrass (TRGA1 and TRGA2) and seashore paspalum cultivars (TRGA3) using primers designed from bermudagrass-resistance gene analogs (BRGA) and expressed sequence tag (EST) sequences. Conserved amino acids (highlighted light blue) and conserved domains of the nucleotide binding site (NBS) or leucine-rich repeat (highlighted in green) between the TRGA and BRGA/ESTs are shown. TRGA1-3 are listed as GenBank accession numbers GU247047-GU247049. SI1 is 'Sea Isle 1'. TRGA1 spans the end of the leucine-rich repeat to the C-terminal region. Underlined amino acids represent the primer sites. 